\title{
Ethnic persistence, assimilation and risk proclivity
}

\author{
Holger Bonin ${ }^{1}$, Amelie Constant ${ }^{2}$, Konstantinos Tatsiramos ${ }^{3}$ and Klaus F Zimmermann ${ }^{4 *}$
}

\footnotetext{
* Correspondence: Zimmermann@ iza.org

${ }^{4}$ IZA and Bonn University, IZA, P.O. Box 7240, Bonn D-53072, Germany Full list of author information is available at the end of the article
}

\begin{abstract}
This paper investigates whether immigrants adapt to the attitudes of the majority population in the host country by focusing on the effect of ethnic persistence and assimilation on individual risk proclivity. Employing information from a unique representative German survey, we find that adaptation to the host country closes the existing immigrant-native gap in risk proclivity by reducing immigrants' risk aversion and explains the systematic variation in the observed risk attitudes across immigrants of different origins. Our analysis of the adaptation behavior of immigrants suggests that acquisition of social norms is an essential factor in the formation of individual attitudes.

JEL classification: D1, D81, F22, J15, J16, J31, J62, J82

Keywords: Risk attitudes, Ethnic persistence, Assimilation, Second generation effects, Gender
\end{abstract}

\section{Introduction}

Risk attitudes are a personal trait that affects human behavior and economic decisionmaking in many domains of life. They have been observed to be persistently different across educational levels, gender and ethnicities (Rivers et al. 2010). Individual attitudes towards risk, whether being risk loving or risk averse, gravely impinge on portfolio choices, contracting, family formation, and human capital formation. Risk proclivity is relevant concerning selection into occupations, and the readiness to become selfemployed (Ekelund et al. 2005). Individuals who are more prone to take risks also earn significantly higher wages (Bonin et al. 2007). As the willingness to take risks affects and amplifies economic outcomes, systematic differences in risk attitudes across different socioeconomic groups have wide implications for understanding economic dissimilarities across these groups.

Despite the great economic importance of risk proclivity, so far very little is known about the determinants of individual risk attitudes. A small empirical literature on the formation of personal traits and attitudes highlights the role of transmission from parents to children. ${ }^{1}$ However, another possible determinant of individual attitudes is prevailing social norms. This paper aims at testing this hypothesis by studying the adaptation process of immigrants to the risk proclivity of the majority population in the host country.

The behavior of immigrants can provide valuable insights because there appear to be systematic differences in risk attitudes or proclivity across individuals of different ethnicities. Bonin et al. (2009) provide evidence that foreign nationals are significantly

(c) 2012 Bonin et al.; licensee Springer. This is an Open Access article distributed under the terms of the Creative Commons Attribution License (http://creativecommons.org/licenses/by/2.0), which permits unrestricted use, distribution, and reproduction in any medium, provided the original work is properly cited. 
less willing to take risks than natives. They also observe substantial differences across immigrants from different ethnicities. Finally, the children of immigrants born and raised in Germany appear to be more similar to natives, in terms of risk attitudes, than the immigrants born abroad. This suggests that the immigrant-native gap in average risk attitudes might not be persistent.

If immigrants adapt to the risk proclivity of the majority population in the host country, this implies systematic heterogeneity. We hypothesize that the gap in risk proclivity between immigrants and natives is larger for those immigrants who stick more closely to their ethnic origin, and smaller for those who are better assimilated to and identify with the host country society. To examine this hypothesis, the paper studies the relationship of ethnic persistence, assimilation, and risk proclivity. We use a slew of questions on the willingness to take risks and on the ethnic identity of immigrants as stated in a unique representative survey on foreign nationals and natives living in Germany. Using factor analysis, we construct measures of ethnic persistence and assimilation to help explain the differences and correlations in declared risk behavior.

The paper is organized as follows: Section 2 introduces the data used in the study and the constructed risk measures. Section 3 describes the construction of measures of ethnic persistence and assimilation based on factor analysis. Section 4 outlines the empirical findings. Section 5 concludes.

\section{The data}

Our analysis is based on a sample of individuals over the age of 17 drawn from the 2004 wave of the German Socio-Economic Panel (GSOEP). The GSOEP is designed to be representative of the German population; both natives and immigrants (see Schupp and Wagner 2002 for a detailed description). While the survey has been conducted since 1984, it was only in 2004 when individuals were asked a novel battery of questions about their risk attitudes. The key question on risk requests survey participants to indicate their willingness to take risks on an 11-point scale, with zero corresponding to complete unwillingness to take risks, and ten corresponding to complete willingness to take risks. ${ }^{2}$ The questionnaire continues with five additional questions using the same wording and the same scale. These questions probe respondents on their risk proclivity in specific contexts: car driving, financial matters, sports and leisure, career, and health.

A potential issue with survey measures of risk proclivity is that individuals could misreport their true attitudes due to, for example, self-servicing bias or strategic motives (Camerer and Hogarth 1999). In our context, however, we can be confident about the behavioral validity of the survey measures, because the particular set of questions has reliably predicted actual risk taking behavior in a large-scale, incentive compatible lottery experiment with real money at stake (Dohmen et al. 2011).

Our sample represents all major ethnic groups of immigrants living in Germany. We classify them according to their passport as follows: Turks, Balkans (from the former Yugoslavia and other Balkan countries), South Europeans (from Greece, Italy, Spain, and Portugal), East Europeans, West Europeans, and immigrants of other origin. We furthermore distinguish between immigrants who are born abroad, henceforth referred to as the "first generation immigrants", and immigrants born in Germany ${ }^{3}$ henceforth referred to as the "second generation immigrants". 
In Table 1 we present the summary statistics of our sample containing 18,600 individuals. ${ }^{4}$ Column 1 contains the mean characteristics for the total sample of immigrants and natives. About $6 \%$ of the sample consists of individuals with foreign nationality. Among immigrants, Turks form the largest ethnic group (31.9\%) representing 1.9\% of the total population. They are followed by south Europeans (27.6\%), the Balkans (19.4\%) and the west Europeans (10.7\%). Immigrants from other east European countries and the rest of the world have a share of $5.5 \%$ and $4.6 \%$, respectively.

Comparing immigrants to natives, Columns 3 and 5 show that there is a larger share of women among the natives (52.1\%) than among the immigrants (48.0\%), that immigrants are in the average about five years younger, have a more than one year lower education, a higher share (ten percentage points) of them is married, and they have an only marginally lower net household income measured in 10,000 Euros. The descriptive statistics also show that immigrants, according to our survey measure of risk attitudes, are on average more risk averse than native Germans. Concerning the willingness to take risks "in general", the unconditional gap to natives is about 0.5 points on the 11-point-scale. Considering risk attitudes with regard to specific domains of life, the immigrant-native gap ranges from 0.2 to 0.5 points.

\section{Factor analysis of ethnic identification}

This section explains our construction of the measures that quantify the degree of ethnic persistence and assimilation that we use later as characteristics to explain the

Table 1 Descriptive sample statistics

\begin{tabular}{|c|c|c|c|c|c|c|}
\hline \multirow[t]{2}{*}{ Characteristics } & \multicolumn{2}{|c|}{ Total sample } & \multicolumn{2}{|c|}{ Immigrants } & \multicolumn{2}{|c|}{ Natives } \\
\hline & Mean & St.Dev. & Mean & St.Dev. & Mean & St.Dev. \\
\hline Female & 0.518 & 0.499 & 0.480 & 0.499 & 0.521 & 0.495 \\
\hline Age & 48.85 & 16.66 & 44.03 & 14.58 & 49.17 & 16.74 \\
\hline Years of education & 12.14 & 2.680 & 10.81 & 2.595 & 12.220 & 2.660 \\
\hline Married & 0.638 & 0.480 & 0.739 & 0.432 & 0.631 & 0.482 \\
\hline Household income & 0.280 & 0.222 & 0.259 & 0.323 & 0.281 & 0.214 \\
\hline Living in east Germany & 0.249 & 0.432 & 0.006 & 0.077 & 0.265 & 0.441 \\
\hline Foreign nationality & 0.062 & 0.241 & 1.0 & 0.0 & & \\
\hline Turk & 0.019 & 0.139 & 0.319 & 0.466 & & \\
\hline Balkan & 0.012 & 0.109 & 0.194 & 0.395 & & \\
\hline South European & 0.017 & 0.129 & 0.276 & 0.447 & & \\
\hline West European & 0.006 & 0.081 & 0.107 & 0.309 & & \\
\hline East European & 0.003 & 0.058 & 0.055 & 0.228 & & \\
\hline Other & 0.002 & 0.053 & 0.046 & 0.211 & & \\
\hline \multicolumn{7}{|c|}{ Willingness to take risk towards: } \\
\hline General & 4.385 & 2.357 & 3.945 & 2.618 & 4.414 & 2.335 \\
\hline Driving & 2.919 & 2.516 & 2.742 & 2.659 & 2.930 & 2.506 \\
\hline Financial & 2.395 & 2.205 & 2.246 & 2.338 & 2.405 & 2.196 \\
\hline Leisure & 3.390 & 2.560 & 2.922 & 2.598 & 3.421 & 2.555 \\
\hline Career & 3.563 & 2.693 & 3.066 & 2.762 & 3.596 & 2.684 \\
\hline Health & 2.906 & 2.431 & 2.766 & 2.461 & 2.915 & 2.429 \\
\hline No. of observations & 18,600 & & 1,154 & & 17,446 & \\
\hline
\end{tabular}


individuals risk attitudes. Following Constant et al. (2009) we start with a number of variables available in the 2003 and 2004 waves of GSOEP that provide information on the immigrants' commitment to the culture and society of origin and devotion to the host society. These variables cover four salient features of immigrants' ethnic identity, namely self-identification, language, ethnic interaction, and intentions to return to the country of origin.

We construct the self-identification variable from questions asking to what extent do immigrants see themselves as Germans, and to what extent they feel that they belong to the culture and society of the country of origin. Proficiency in the host country's language is captured by questions on the main language spoken at home, and the type of newspapers (German or foreign) read. The ethnic interaction variable is formed from information on whether immigrants socialize with Germans and have visited Germans in their home within the last 12 months. Intentions to return are constructed from self-reported answers on whether immigrants want to remain in Germany permanently. We recode all these five variables such that a higher score indicates a weaker commitment to the host country, and a stronger commitment to the country of origin.

In order to gather the information contained in these variables, i.e., to learn if the observed variables can be explained in terms of a smaller set of variables, we employ factor analysis. Factor analysis aims at generating a set of orthogonal (uncorrelated) latent variables, the so-called factors, which reproduce the correlation or covariance matrix of a given set of variables as closely as possible. This approach has several advantages. First, it allows for a more parsimonious specification of the empirical model eschewing multicollinearity. Second, it groups interdependent variables into descriptive categories that allow profiling individuals into types with similar characteristics or behavior. Finally, the factors represent a scale with which individuals or groups of individuals can be compared. An issue that arises when developing a measure for such phenomena as ethnic persistence or assimilation is how to weigh the characteristics being combined. Factor analysis offers a solution by dividing the characteristics into independent sources of variation. Each factor represents a measure based on the empirical relationships between the underlying characteristics.

A practical issue is to determine the number of relevant factors, which involves a certain amount of subjective judgment. The key criterion is the contribution of each factor to explaining the total variance in the observed outcome variables. To extract the relevant factors, we rely on the principal-component factor method, which standardizes the variance of each observed variable to unity. Due to the standardization, the explained variance is given by the respective eigenvalue of the unrotated factors. $^{5}$

Table 2 displays the eigenvalues for each of the six potential factors. It is clear that the first two factors taken together account for the majority of the total variance in the six variables. The first factor has an eigenvalue of 2.55 , which means that it accounts for 42.5 percent of the standardized total variance of 6 . Although the second factor only accounts for 18.1 percent of the total variance, it has an eigenvalue larger than one. This means that it still extracts more variance than the equivalent of one original variable.

All remaining factors exhibit eigenvalues smaller than one. The Kaiser criterion tells us that we should not retain these factors, as they extract less variation than the 
Table 2 Factor analysis - Principal component factors

\begin{tabular}{lcccc}
\hline Factors & Eigenvalue & Difference & Proportion & Cumulative \\
\hline Factor 1 & 2.551 & 1.463 & 0.425 & 0.425 \\
Factor 2 & 1.088 & 0.332 & 0.181 & 0.607 \\
Factor 3 & 0.756 & 0.074 & 0.126 & 0.733 \\
Factor 4 & 0.682 & 0.151 & 0.114 & 0.846 \\
Factor 5 & 0.531 & 0.140 & 0.089 & 0.935 \\
Factor 6 & 0.392 & & 0.065 & 1 \\
\hline
\end{tabular}

equivalent of the original variables. The scree test, a graphical method, leads to the same conclusion. This test suggests keeping the factors up to the point where the smooth decrease of eigenvalues appears to level off to the right of a simple line plot. Table 2 shows that, starting from factor 3, the differences between the eigenvalues become small. Therefore, in the following analysis, we keep only the first two factors.

In Table 3 we present the factor loadings attached to these two factors and the communality for each of the six original outcome variables that measure ethnic persistence and assimilation. In factor analysis parlance, factor loadings are the correlations between the variables and the two factors, as they are extracted by default, and communality refers to the proportion of each variable's variance explained by the suggested factor structure (or the proportion of variance due to common factors). The explanatory power of the two factors appears quite satisfactory. In fact, taken together they explain 50-70 percent of the variance in the observed outcome variables.

Next, we characterize the two factors. The factor loadings indicate that the first factor exhibits a strong negative correlation with the degree of "feeling German" and the use of German newspapers. At the same time, factor 1 shows strong positive correlations with the immigrants' attachment to their country of origin, and the use of a foreign language at home. This pattern of factor loadings suggests that a higher value on the scale of factor 1 is associated with a stronger commitment of the immigrants to their origin. This indicates a form of ethnic separation from the host country. In the following, we refer to factor 1 as ethnic persistence.

The factor loadings of the second factor demonstrate a distinguished positive correlation with speaking German at home, the use of German newspapers and the interaction with Germans. Compared to the loadings of factor 1, a higher value of factor 2 is also associated with a higher degree of feeling German and a weaker degree of connection to the home country. This pattern suggests that a higher value on the scale of factor 2 is associated with a stronger identification of the immigrants with the host

Table 3 Factor loadings (pattern matrix) and unique variances

\begin{tabular}{lccc}
\hline Variables & Factor $\mathbf{1}$ & Factor $\mathbf{2}$ & Communality \\
\hline Feeling German & -0.748 & -0.268 & 0.632 \\
Connected with the country of origin & 0.636 & 0.404 & 0.568 \\
Speaking foreign language at home & 0.777 & -0.313 & 0.702 \\
Paying no visits to Germans & 0.563 & -0.451 & 0.521 \\
Not remain in Germany permanently & 0.402 & 0.669 & 0.609 \\
Reading German newspapers & -0.710 & 0.322 & 0.608 \\
\hline
\end{tabular}


country. We therefore refer to factor 2 as assimilation. Note that the degree of assimilation appears especially associated with familiarity with the German language.

On the basis of the factor loadings and the observed outcome variables, we may predict the realizations of the two factors for each individual immigrant. By construction the factors are centered on zero when looking at the complete sample of immigrants. A higher value on the scale for ethnic persistence indicates that an individual is more strongly committed to and identifies with the country of origin and a higher value on the scale for assimilation indicates stronger identification with the host country.

In Table 4 we provide summary statistics for the ethnic persistence and assimilation factors estimated on the sample of immigrants. It is evident that there are substantial differences in the factors by country of ancestry and place of birth across the immigrant population. Concerning the ethnic persistence factor, Turks appear as the group most committed to their origin, followed by immigrants originating from the Balkans and south Europe. As expected, immigrants from west Europe rank the lowest on the ethnic persistence scale. When we compare immigrants born abroad with immigrants born in Germany, the latter are substantially less committed to the country of ancestry than the former. This pattern holds for all nationality groups.

With regard to the assimilation factor, we observe a related pattern. As a group, the West Europeans occupy the highest position on this scale, whereas Turks occupy the lowest. Immigrants from Eastern Europe rank the second least-assimilated group; which is plausible since most of them have arrived only recently in Germany. Compared to the ethnic persistence factor, the distinction between the first and second generation immigrants is generally less clear when it comes to the assimilation factor. ${ }^{6}$ Somewhat

Table 4 Summary statistics of factors

\begin{tabular}{|c|c|c|c|c|}
\hline \multirow[t]{3}{*}{ Characteristics } & \multicolumn{4}{|c|}{ Factors } \\
\hline & \multicolumn{2}{|c|}{ Ethnic persistence } & \multicolumn{2}{|c|}{ Assimilation } \\
\hline & Mean & St.Dev. & Mean & St.Dev. \\
\hline Turk & 0.496 & 1.029 & -0.330 & 0.943 \\
\hline Balkan & -0.252 & 0.871 & 0.018 & 0.935 \\
\hline South European & -0.121 & 0.909 & 0.174 & 0.955 \\
\hline West European & -0.590 & 0.835 & 0.402 & 0.958 \\
\hline East European & -0.079 & 0.873 & -0.160 & 1.052 \\
\hline Other & -0.177 & 0.885 & 0.420 & 1.191 \\
\hline Turk born abroad & 0.663 & 0.995 & -0.400 & 0.942 \\
\hline Balkan born abroad & -0.122 & 0.857 & 0.028 & 0.979 \\
\hline South European born abroad & 0.034 & 0.889 & 0.171 & 0.963 \\
\hline West European born abroad & -0.467 & 0.791 & 0.483 & 0.947 \\
\hline East European born abroad & -0.079 & 0.873 & -0.160 & 1.052 \\
\hline Other born abroad & -0.192 & 0.904 & 0.373 & 1.216 \\
\hline Turk born in Germany & -0.342 & 0.754 & 0.022 & 0.877 \\
\hline Balkan born in Germany & -0.910 & 0.604 & -0.031 & 0.685 \\
\hline South European born in Germany & -0.544 & 0.828 & 0.181 & 0.940 \\
\hline West European born in Germany & -1.361 & 0.697 & -0.110 & 0.890 \\
\hline \multicolumn{5}{|l|}{ East European born in Germany } \\
\hline Other born in Germany & 0.010 & 0.677 & 0.999 & 0.668 \\
\hline
\end{tabular}


surprisingly, when we compare immigrants born abroad and in Germany, the only group showing a significant improvement on the assimilation scale is the Turks.

\section{Empirical results}

\subsection{Explaining general risk proclivity without factors}

We now turn to the core part of our analysis, where we study the relationship between the individuals' ranking on the ethnic persistence and assimilation scales, and their revealed risk proclivity controlling for a number of other determinants. We start by analyzing the determinants of the survey responses to the question on the willingness to take risks in general, without controlling for the factors measuring ethnic persistence and assimilation. Table 5 shows the estimation results from linear regressions using the individuals' position on the $0-10$ risk scale as the dependent variable. ${ }^{7}$ As general control variables we use age (in a cubic specification), gender (female), body height, marriage status, years of education and household net income, all of which are well known to have a significant impact on risk behavior. We also include a dummy for "living in eastern Germany." Since very few immigrants in our sample live in the east, we want to compare them to the reference group of west German natives.

The different specifications control for ethnic background in various ways: (i) by including a dummy, which is equal to one if individuals have a foreign nationality, (ii) by an interaction of foreign nationality with a dummy equal to one if an individual is born abroad, and (iii) by interacting the foreign nationality dummy, and its interaction with the being born abroad dummy, with indicators for the different ethnic groups.

Column 1 of Table 5 indicates that after taking into account individual heterogeneity, immigrants are less willing to take risks than natives. Interacting the foreign nationality dummy with the dummy for being born in Germany in Column 2 we find that the first generation immigrants, as captured by the coefficient of foreign nationality, are more risk averse than natives. Second generation immigrants, however, are less risk averse than the first generation and their risk attitudes do not differ compared to native Germans. This conclusion is based on a test of the hypothesis that the sum of the two coefficients equals zero, which we fail to reject.

In Column 3 we report estimation results for the effect of foreign nationality on general risk proclivity by different immigrant groups. The effects are significant for Turks, Balkans, and south Europeans. While we distinguish between first and second generation immigrants in Column 4 this does not alter the results: (i) The first generation immigrants from these three immigrant groups are more risk averse than the native Germans, and (ii) the risk attitudes of the second generation immigrants do not differ from those of the native population.

\subsection{General risk proclivity, ethnic persistence and assimilation}

In this section we analyze the role of ethnic persistence and assimilation in explaining the peculiar risk attitudes of immigrants of different countries of origin, and of the first and second generation immigrants. In Table 6 we report the results from estimations repeating the specifications discussed in the previous section, but that now include as explanatory variables the ethnic persistence and assimilation factors predicted for the individuals. This exercise reveals that the higher the value of our ethnic persistence measure is, that is, the stronger immigrants are attached to their country of origin, the 
Table 5 Dependent variable - General risk - Full sample

\begin{tabular}{|c|c|c|c|c|}
\hline Independent variables & $(1)$ & (2) & (3) & (4) \\
\hline \multirow[t]{2}{*}{ Constant } & $2.962^{* * *}$ & $2.934^{* * *}$ & $3.117^{* * *}$ & $3.116^{* * *}$ \\
\hline & $(0.595)$ & $(0.595)$ & $(0.595)$ & $(0.595)$ \\
\hline \multirow[t]{2}{*}{ Foreign nationality } & $-0.380^{* * *}$ & $-0.474^{* * *}$ & & \\
\hline & $(0.092)$ & $(0.097)$ & & \\
\hline \multirow[t]{2}{*}{ Foreign nationality* born in Germany } & & $0.525^{* * *}$ & & \\
\hline & & $(0.203)$ & & \\
\hline \multirow[t]{2}{*}{ Turk } & & & $-0.781^{* * *}$ & $-0.885^{* * *}$ \\
\hline & & & $(0.177)$ & $(0.191)$ \\
\hline \multirow[t]{2}{*}{ Balkan } & & & $-0.433^{* *}$ & $-0.590^{* * *}$ \\
\hline & & & $(0.190)$ & $(0.194)$ \\
\hline \multirow[t]{2}{*}{ South European } & & & $-0.289^{*}$ & $-0.362^{*}$ \\
\hline & & & $(0.170)$ & $(0.187)$ \\
\hline \multirow[t]{2}{*}{ West European } & & & 0.224 & 0.144 \\
\hline & & & $(0.197)$ & $(0.218)$ \\
\hline \multirow[t]{2}{*}{ East European } & & & -0.160 & -0.160 \\
\hline & & & $(0.257)$ & $(0.257)$ \\
\hline \multirow[t]{2}{*}{ Other } & & & 0.212 & 0.053 \\
\hline & & & $(0.389)$ & $(0.403)$ \\
\hline \multirow[t]{2}{*}{ Foreign nationality * born in Germany * Turk } & & & & 0.613 \\
\hline & & & & $(0.399)$ \\
\hline \multirow[t]{2}{*}{ Foreign nationality * born in Germany * Balkan } & & & & $0.941^{* *}$ \\
\hline & & & & $(0.443)$ \\
\hline Foreign nationality * born in Germany * South & & & & 0.258 \\
\hline European & & & & $(0.327)$ \\
\hline Foreign nationality * born in Germany * West & & & & 0.573 \\
\hline European & & & & $(0.451)$ \\
\hline \multicolumn{5}{|l|}{ Foreign nationality * born in Germany * East } \\
\hline \multicolumn{5}{|l|}{ European } \\
\hline \multirow[t]{2}{*}{ Foreign nationality * born in Germany * Other } & & & & $2.146^{*}$ \\
\hline & & & & $(1.214)$ \\
\hline \multirow[t]{2}{*}{ Age } & $-0.109^{* * *}$ & $-0.106^{* * *}$ & $-0.109^{* * *}$ & $-0.105^{* * *}$ \\
\hline & $(0.022)$ & $(0.022)$ & $(0.022)$ & $(0.022)$ \\
\hline \multirow[t]{2}{*}{$\mathrm{Age}^{2} / 100$} & $0.200^{* * *}$ & $0.196^{* * *}$ & $0.199^{* * *}$ & $0.194^{* * *}$ \\
\hline & $(0.045)$ & $(0.045)$ & $(0.045)$ & $(0.045)$ \\
\hline \multirow[t]{2}{*}{$\mathrm{Age}^{3} / 10,000$} & $-0.151^{* * *}$ & $-0.149^{* * *}$ & $-0.149^{* * *}$ & $-0.147^{* * *}$ \\
\hline & $(0.029)$ & $(0.029)$ & $(0.029)$ & $(0.029)$ \\
\hline \multirow[t]{2}{*}{ Female } & $-0.659^{* * *}$ & $-0.662^{* * *}$ & $-0.672^{* * *}$ & $-0.678^{* * *}$ \\
\hline & $(0.044)$ & $(0.044)$ & $(0.045)$ & $(0.045)$ \\
\hline \multirow[t]{2}{*}{ Body height in centimeters } & $0.017^{* * *}$ & $0.017^{* * *}$ & $0.017^{* * *}$ & $0.016^{* * *}$ \\
\hline & $(0.003)$ & $(0.003)$ & $(0.003)$ & $(0.003)$ \\
\hline \multirow[t]{2}{*}{ Married } & $-0.255^{* * *}$ & $-0.254^{* * *}$ & $-0.248^{* * *}$ & $-0.245^{* * *}$ \\
\hline & $(0.042)$ & $(0.042)$ & $(0.042)$ & $(0.042)$ \\
\hline \multirow[t]{2}{*}{ Living in eastern Germany } & $0.276^{* * *}$ & $0.276^{* * *}$ & $0.274^{* * *}$ & $0.273^{* * *}$ \\
\hline & $(0.043)$ & $(0.043)$ & $(0.043)$ & $(0.043)$ \\
\hline
\end{tabular}


Table 5 Dependent variable - General risk - Full sample (Continued)

\begin{tabular}{lllll}
\hline Years of education & $0.085^{* * *}$ & $0.085^{* * *}$ & $0.083^{* * *}$ & $0.082^{* * *}$ \\
Household net income & $(0.007)$ & $(0.007)$ & $(0.007)$ & $(0.007)$ \\
& $0.805^{* * *}$ & $0.806^{* * *}$ & $0.786^{* * *}$ & $0.789^{* * *}$ \\
R-squared & $(0.124)$ & $(0.123)$ & $(0.125)$ & $(0.125)$ \\
No. of observations & 0.139 & 0.139 & 0.14 & 0.141 \\
\hline
\end{tabular}

a Robust standard errors in parentheses clustered at the household level.

* significant at $10 \%$; ** at $5 \%$; *** at $1 \%$.

higher the degree of risk aversion is. At the same time, our assimilation measure shows a positive and significant effect on the degree to which individuals are willing to take risks. These findings are consistent across all specifications in Table 6.

These results have a number of implications. First, as the population share of immigrants who rank high on the scale of ethnic persistence and low on the scale of assimilation is substantial, we can explain part of the overall migrant-native gap in risk attitudes. Second, given that the average position on the ethnic persistence and assimilation scales varies systematically across the groups of immigrants, we can explain systematic variation in the observed risk attitudes across immigrants of different country of origin.

To illustrate this point, we use a counterfactual simulation in which we focus on groups of immigrants with the highest (lowest) average value on the ethnic persistence scale and the lowest (highest) average value on the assimilation scale. These are the Turks and West Europeans. ${ }^{8}$ In the first step, we predict the average risk attitudes for the two groups on the basis of the estimated model in column 3 of Table 6 . The prediction yields an average risk attitude level for Turks of 3.51, and for West European immigrants of 4.77. In the second step, we maintain all individual characteristics of the two groups except the ethnic persistence and assimilation measures; we now endow Turks with the average values of western immigrants and western immigrants with the average values of Turks. The result of this thought experiment shows that the gap in predicted average risk attitudes by ethnic origin becomes substantially smaller: If Turks (western immigrants) had the same degree of ethnic persistence and assimilation as western immigrants (Turks), the gap in average risk attitudes would fall from 1.26 to 0.38. The predicted average risk attitude level for Turks becomes 3.95, while for West Europeans 4.33.

Comparing the results in Table 5 and Table 6 we observe that even when we take into account individual differences on the degree of attachment to the host and origin countries, in Table 6 (columns 1 and 2), foreign nationals are less willing to take risks compared to natives. Also the results for the specific risk attitudes of Turks, Balkans and south Europeans, still hold (columns 3 and 4). However, in contrast to the results in Table 5, the risk attitudes of the second generation immigrants do not differ significantly from those of the first generation, though we still cannot reject the hypothesis that the behavior of the second generation immigrants is different from those of natives. An interpretation of this result is that individuals of foreign origin adapt and assimilate to host country attitudes through the education system or the mere exposure to the host country's lifestyle. At the same time, they do not differ much from their 
Table 6 Dependent variable - General risk - Full sample with factors

\begin{tabular}{|c|c|c|c|c|}
\hline Independent variables & (1) & (2) & (3) & (4) \\
\hline \multirow[t]{2}{*}{ Constant } & $3.066^{* * *}$ & $3.041^{* * *}$ & $3.139^{* * *}$ & $3.143^{* * *}$ \\
\hline & $(0.595)$ & $(0.595)$ & $(0.595)$ & $(0.595)$ \\
\hline \multirow[t]{2}{*}{ Ethnic Persistence Factor } & $-0.296^{* * *}$ & $-0.263^{* * *}$ & $-0.242^{* * *}$ & $-0.195^{* *}$ \\
\hline & $(0.080)$ & $(0.083)$ & $(0.086)$ & $(0.092)$ \\
\hline \multirow[t]{2}{*}{ Assimilation Factor } & $0.289^{* * *}$ & $0.284^{* * *}$ & $0.245^{* * *}$ & $0.236^{* * *}$ \\
\hline & $(0.081)$ & $(0.081)$ & $(0.082)$ & $(0.084)$ \\
\hline \multirow[t]{2}{*}{ Foreign nationality } & $-0.387^{* * *}$ & $-0.442^{* * *}$ & & \\
\hline & $(0.092)$ & $(0.097)$ & & \\
\hline \multirow[t]{2}{*}{ Foreign nationality* born in Germany } & & 0.306 & & \\
\hline & & $(0.212)$ & & \\
\hline \multirow[t]{2}{*}{ Turk } & & & $-0.584^{* * *}$ & $-0.664^{* * *}$ \\
\hline & & & $(0.189)$ & $(0.213)$ \\
\hline \multirow[t]{2}{*}{ Balkan } & & & $-0.501^{* * *}$ & $-0.622^{* * *}$ \\
\hline & & & $(0.190)$ & $(0.194)$ \\
\hline \multirow[t]{2}{*}{ South European } & & & $-0.364^{* *}$ & $-0.399^{* *}$ \\
\hline & & & $(0.171)$ & $(0.185)$ \\
\hline \multirow[t]{2}{*}{ West European } & & & -0.017 & -0.062 \\
\hline & & & $(0.210)$ & $(0.230)$ \\
\hline \multirow[t]{2}{*}{ East European } & & & -0.139 & -0.137 \\
\hline & & & $(0.257)$ & $(0.257)$ \\
\hline \multirow[t]{2}{*}{ Other } & & & 0.067 & -0.072 \\
\hline & & & $(0.385)$ & $(0.400)$ \\
\hline \multirow[t]{2}{*}{ Foreign nationality * born in Germany * Turk } & & & & 0.322 \\
\hline & & & & $(0.419)$ \\
\hline \multirow[t]{2}{*}{ Foreign nationality * born in Germany * Balkan } & & & & $0.806^{*}$ \\
\hline & & & & $(0.441)$ \\
\hline Foreign nationality * born in Germany * South & & & & 0.149 \\
\hline European & & & & $(0.329)$ \\
\hline Foreign nationality * born in Germany * West & & & & 0.541 \\
\hline European & & & & $(0.462)$ \\
\hline \multicolumn{5}{|l|}{ Foreign nationality * born in Germany * East } \\
\hline \multicolumn{5}{|l|}{ European } \\
\hline \multirow[t]{2}{*}{ Foreign nationality * born in Germany * Other } & & & & 2.039 \\
\hline & & & & $(1.261)$ \\
\hline \multirow[t]{2}{*}{ Age } & $-0.109^{* * *}$ & $-0.107^{* * *}$ & $-0.109^{* * *}$ & $-0.107^{* * *}$ \\
\hline & $(0.022)$ & $(0.022)$ & $(0.022)$ & $(0.022)$ \\
\hline \multirow[t]{2}{*}{$\mathrm{Age}^{2} / 100$} & $0.201^{* * *}$ & $0.199^{* * *}$ & $0.200^{* * *}$ & $0.197^{* * *}$ \\
\hline & $(0.045)$ & $(0.045)$ & $(0.045)$ & $(0.045)$ \\
\hline \multirow[t]{2}{*}{$\mathrm{Age}^{3} / 10,000$} & $-0.151^{* * *}$ & $-0.150^{* * *}$ & $-0.151^{* * *}$ & $-0.149^{* * *}$ \\
\hline & $(0.029)$ & $(0.029)$ & $(0.029)$ & $(0.029)$ \\
\hline \multirow[t]{2}{*}{ Female } & $-0.666^{* * *}$ & $-0.667^{* * *}$ & $-0.673^{* * *}$ & $-0.677^{* * *}$ \\
\hline & $(0.044)$ & $(0.044)$ & $(0.045)$ & $(0.045)$ \\
\hline \multirow[t]{2}{*}{ Body height in centimeters } & $0.017^{* * *}$ & $0.017^{* * *}$ & $0.017^{* * *}$ & $0.016^{* * *}$ \\
\hline & $(0.003)$ & $(0.003)$ & $(0.003)$ & $(0.003)$ \\
\hline
\end{tabular}




\begin{tabular}{lllll} 
Table 6 Dependent variable - General risk - Full sample with factors & (Continued) \\
\hline Married & $-0.245^{* * *}$ & $-0.245^{* * *}$ & $-0.244^{* * *}$ & $-0.243^{* * *}$ \\
& $(0.042)$ & $(0.042)$ & $(0.042)$ & $(0.042)$ \\
Living in eastern Germany & $0.275^{* * *}$ & $0.275^{* * *}$ & $0.274^{* * *}$ & $0.273^{* * *}$ \\
& $(0.043)$ & $(0.043)$ & $(0.043)$ & $(0.043)$ \\
Years of education & $0.083^{* * *}$ & $0.083^{* * *}$ & $0.082^{* * *}$ & $0.081^{* * *}$ \\
& $(0.007)$ & $(0.007)$ & $(0.007)$ & $(0.007)$ \\
Household net income & $0.798^{* * *}$ & $0.798^{* * *}$ & $0.788^{* * *}$ & $0.790^{* * *}$ \\
& $(0.124)$ & $(0.123)$ & $(0.125)$ & $(0.125)$ \\
R-squared & 0.141 & 0.1412 & 0.1414 & 0.1419 \\
No. of observations & 18,518 & 18,518 & 18,518 & 18,518 \\
\hline
\end{tabular}

a Robust standard errors in parentheses clustered at the household level.

* significant at $10 \%$; ** at $5 \%$; *** at $1 \%$.

parents, and this is consistent with the established fact that an important source of an individual's personal tastes and traits is the tastes and traits of the parents.

For a robustness check, we disaggregate the immigrant sample by gender and repeat the previous analysis. The estimation results presented in Table 7 show that the ethnic persistence factor is negatively correlated with the willingness to take risks for both men and women across the board. The impact of the assimilation factor is positive and significant for males in all specifications. For females, it is also positive throughout, but the estimated coefficients become statistically insignificant in the specifications containing separate ethnic groups. Still the overall impression is that the main findings for the total population in Table 6 hold irrespective of gender. This includes the impact of immigrant status versus natives, the systematic differences between different countries of origin, and the distinction between first and second generation immigrants.

\subsection{Specific risk proclivity}

In this section we focus on the analysis of risk proclivity concerning specific domains of life. This exercise could bring about additional information, since the covariance matrix of the answers given by individuals to the battery of risk attitude questions shows a substantial deal of independent variation. Thus the analysis of specific risk proclivity provides another robustness check of our previous findings.

Table 8 reports the estimation results for different risk proclivity including the ethnic persistence and assimilation factors using the same specification as in Column 2 of Table 6 explaining general risk proclivity. The coefficients exhibit that the ethnic persistence factor is negative concerning almost all different risk facets, except the risk proclivity with regard to the financial portfolio where the coefficient is basically zero. The estimated parameter is significant for risk proclivity in the domain of driving, leisure and sports, and career. The coefficient on the assimilation factor is generally positive and is significant for the general, leisure and sports, and career risk attitudes.

Turning to the effect of first generation immigrants, we find that it is also negative and significant for all different risk attitudes except those related to health. Consistent with our previous findings, second generation immigrants do not differ significantly from natives. The only exception is risk attitudes towards leisure and sports where both first and second generation immigrants are more risk averse than natives. This 
Table 7 Dependent variable - General risk - By gender with factors

\begin{tabular}{|c|c|c|c|c|c|c|c|c|}
\hline \multirow[b]{2}{*}{ Independent variables } & \multicolumn{4}{|c|}{ Males } & \multicolumn{4}{|c|}{ Females } \\
\hline & (1) & (2) & $(3)$ & (4) & (5) & (6) & (7) & (8) \\
\hline \multirow[t]{2}{*}{ Constant } & $2.400^{* * *}$ & $2.425^{* * *}$ & $2.369^{* * *}$ & $2.408^{* * *}$ & $2.980^{* * *}$ & $3.089^{* * *}$ & $2.956^{* * *}$ & $3.102^{* * *}$ \\
\hline & $(0.833)$ & $(0.833)$ & $(0.833)$ & $(0.833)$ & $(0.762)$ & $(0.762)$ & $(0.762)$ & $(0.763)$ \\
\hline \multirow[t]{2}{*}{ Ethnic Persistence Factor } & $-0.297^{* * *}$ & $-0.257^{* *}$ & $-0.261^{* *}$ & $-0.215^{*}$ & $-0.290^{* * *}$ & $-0.201^{* *}$ & $-0.259 * * *$ & -0.153 \\
\hline & $(0.113)$ & $(0.121)$ & $(0.118)$ & $(0.128)$ & $(0.092)$ & $(0.101)$ & $(0.094)$ & $(0.108)$ \\
\hline \multirow[t]{2}{*}{ Assimilation Factor } & $0.355^{* * *}$ & $0.313^{* * *}$ & $0.350^{* * *}$ & $0.304^{* * *}$ & $0.224^{* *}$ & 0.162 & $0.220^{* *}$ & 0.147 \\
\hline & $(0.115)$ & $(0.116)$ & $(0.115)$ & $(0.117)$ & (0.098) & $(0.104)$ & $(0.098)$ & $(0.106)$ \\
\hline \multirow[t]{2}{*}{ Foreign nationality } & $-0.330^{* * *}$ & & $-0.385^{* * *}$ & & $-0.449 * * *$ & & $-0.506^{* * *}$ & \\
\hline & $(0.120)$ & & $(0.127)$ & & $(0.110)$ & & $(0.118)$ & \\
\hline Foreign nationality* born in & & & 0.319 & & & & 0.308 & \\
\hline Germany & & & $(0.293)$ & & & & $(0.284)$ & \\
\hline \multirow[t]{2}{*}{ Turk } & & $-0.485^{* *}$ & & $-0.579^{* *}$ & & $-0.771^{* * *}$ & & $-0.830^{* * *}$ \\
\hline & & $(0.226)$ & & $(0.252)$ & & $(0.244)$ & & $(0.283)$ \\
\hline \multirow[t]{2}{*}{ Balkan } & & $-0.510^{* *}$ & & $-0.542^{* *}$ & & $-0.491^{* *}$ & & $-0.712^{* * *}$ \\
\hline & & $(0.246)$ & & $(0.246)$ & & $(0.226)$ & & $(0.230)$ \\
\hline \multirow[t]{2}{*}{ South European } & & -0.277 & & -0.294 & & $-0.487^{* *}$ & & $-0.575^{* *}$ \\
\hline & & $(0.208)$ & & $(0.213)$ & & $(0.222)$ & & $(0.259)$ \\
\hline \multirow[t]{2}{*}{ West European } & & -0.049 & & -0.183 & & 0.068 & & 0.097 \\
\hline & & $(0.307)$ & & $(0.339)$ & & $(0.272)$ & & $(0.290)$ \\
\hline \multirow[t]{2}{*}{ East European } & & -0.290 & & -0.306 & & -0.023 & & -0.013 \\
\hline & & $(0.425)$ & & $(0.425)$ & & $(0.303)$ & & $(0.303)$ \\
\hline \multirow[t]{2}{*}{ Other } & & 0.767 & & 0.591 & & -0.354 & & -0.493 \\
\hline & & $(0.635)$ & & $(0.643)$ & & $(0.442)$ & & $(0.463)$ \\
\hline Foreign nationality ${ }^{*}$ born in & & & & 0.445 & & & & 0.119 \\
\hline Germany * Turk & & & & $(0.530)$ & & & & $(0.480)$ \\
\hline Foreign nationality ${ }^{*}$ born in & & & & 0.331 & & & & $1.140^{* *}$ \\
\hline Germany * Balkan & & & & $(0.751)$ & & & & $(0.529)$ \\
\hline Foreign nationality * born in & & & & 0.099 & & & & 0.303 \\
\hline Germany * South European & & & & $(0.410)$ & & & & $(0.508)$ \\
\hline Foreign nationality ${ }^{*}$ born in & & & & $1.141^{* *}$ & & & & 0.030 \\
\hline Germany * West European & & & & $(0.552)$ & & & & $(0.647)$ \\
\hline \multicolumn{9}{|l|}{ Foreign nationality * born in } \\
\hline \multicolumn{9}{|l|}{ Germany * East European } \\
\hline Foreign nationality ${ }^{*}$ born in & & & & $4.017^{* * *}$ & & & & 1.676 \\
\hline Germany * Other & & & & $(0.650)$ & & & & $(1.298)$ \\
\hline R-squared & 0.1 & 0.1 & 0.1 & 0.1 & 0.11 & 0.11 & 0.11 & 0.12 \\
\hline No. of observations & 8,916 & 8,916 & 8,916 & 8,916 & 9,602 & 9,602 & 9,602 & 9,602 \\
\hline
\end{tabular}

${ }^{a}$ Robust standard errors in parentheses clustered at the household level.

${ }^{b}$ OLS regressions include additional controls for age, years of education, marital status, total net household income in 10,000 s Euros and body height.

${ }^{*}$ significant at $10 \%$; ${ }^{* *}$ at $5 \%$; ${ }^{* *}$ at $1 \%$.

demonstrates a test on the sum of the two coefficients: the hypothesis that the sum is equal to zero is rejected at the $10 \%$ significance level.

Finally, Table 9 reports the results of the same specifications separated by gender. Once again, we find that the estimated coefficients on the ethnic persistence measure 
Table 8 Dependent variable - Risk attitudes - Full sample with factors

\begin{tabular}{llllll}
\hline & Driving & Financial & Leisure & Career & Health \\
\hline Constant & 0.008 & -0.709 & $3.501^{* * *}$ & -0.499 & $2.347^{* * *}$ \\
& $(0.644)$ & $(0.574)$ & $(0.622)$ & $(0.680)$ & $(0.637)$ \\
Ethnic Persistence Factor & $-0.179^{* *}$ & 0.023 & $-0.184^{* *}$ & $-0.274^{* * *}$ & -0.126 \\
& $(0.086)$ & $(0.074)$ & $(0.081)$ & $(0.083)$ & $(0.085)$ \\
Assimilation Factor & 0.041 & 0.105 & $0.261^{* * *}$ & $0.269^{* * *}$ & -0.005 \\
& $(0.089)$ & $(0.074)$ & $(0.071)$ & $(0.080)$ & $(0.086)$ \\
Foreign nationality & $-0.299^{* * *}$ & $-0.169^{*}$ & $-0.529^{* * *}$ & $-0.387^{* * *}$ & -0.140 \\
& $(0.101)$ & $(0.090)$ & $(0.091)$ & $(0.098)$ & $(0.101)$ \\
Foreign nationality * & -0.010 & $0.357^{*}$ & 0.170 & 0.103 & -0.091 \\
born in Germany & $(0.233)$ & $(0.196)$ & $(0.214)$ & $(0.220)$ & $(0.203)$ \\
R-squared & 0.17 & 0.12 & 0.21 & 0.19 & 0.08 \\
No. of observations & 17,561 & 18,424 & 18,275 & 16,896 & 18,519 \\
\hline
\end{tabular}

${ }^{a}$ Robust standard errors in parentheses clustered at the household level.

* significant at $10 \%$; ** at $5 \%$; *** at $1 \%$.

are mostly negative irrespective of gender, whereas the coefficients on the assimilation factor are mostly positive. However, the estimated parameters become less precise. Still the overall picture is that the individual commitment to the host country (assimilation) or to the ethnic origin (ethnic persistence) have a systematic impact on risk attitudes, and thereby may lead to systematic variation in (economic) outcomes associated with risky behavior.

\section{Conclusion}

This paper makes a contribution to the small economic literature seeking to understand the determinants of personal traits. The results obtained from an empirical analysis of the relationship between ethnic persistence, assimilation and risk proclivity among immigrants in Germany suggests that individual attitudes are to an important degree acquired through adaptation of prevailing social norms. Hence our empirical evidence contrasts and complements earlier studies emphasizing the role of transmission of traits and attitudes from parents to children.

The working hypothesis of this paper is that in the process of assimilation immigrants adapt to the risk attitudes of the majority population in the host country. In order to investigate this hypothesis, we use factor analysis on a set of responses to survey questions measuring closeness or distance to the host and origin countries respectively. Based on this analysis we have constructed measures for the individual degree of ethnic persistence, indicating the commitment to the country of origin, and of assimilation, reflecting the commitment to and identification with the host country.

Our findings suggest that stronger commitment to the country of origin is associated with less willingness to take risks, whereas better assimilation is associated with lower risk aversion. This means ethnic persistence preserves the immigrant-native gap in risk proclivity, while assimilation closes it. The results are fairly robust for risk attitudes concerning different domains of life, in particular financial and career issues, and seem to hold for both men and women. 
Table 9 Dependent variable - Risk attitudes - by gender with factors

\begin{tabular}{|c|c|c|c|c|c|}
\hline Independent variables & Driving & Financial & Leisure & Career & Health \\
\hline \multicolumn{6}{|c|}{ MALES } \\
\hline Constant & $\begin{array}{l}0.011 \\
(0.908)\end{array}$ & $\begin{array}{l}-1.468^{*} \\
(0.841)\end{array}$ & $\begin{array}{l}2.717^{* * *} \\
(0.879)\end{array}$ & $\begin{array}{l}-1.183 \\
(0.965)\end{array}$ & $\begin{array}{l}2.089^{* *} \\
(0.890)\end{array}$ \\
\hline Ethnic Persistence Factor & $\begin{array}{l}-0.225^{*} \\
(0.125)\end{array}$ & $\begin{array}{l}0.064 \\
(0.110)\end{array}$ & $\begin{array}{l}-0.166 \\
(0.117)\end{array}$ & $\begin{array}{l}-0.121 \\
(0.125)\end{array}$ & $\begin{array}{l}0.025 \\
(0.117)\end{array}$ \\
\hline Assimilation Factor & $\begin{array}{l}0.028 \\
(0.132)\end{array}$ & $\begin{array}{l}0.177^{*} \\
(0.100)\end{array}$ & $\begin{array}{l}0.357^{* * *} \\
(0.091)\end{array}$ & $\begin{array}{l}0.289^{* * *} \\
(0.106)\end{array}$ & $\begin{array}{l}0.016 \\
(0.106)\end{array}$ \\
\hline Foreign nationality & $\begin{array}{l}-0.192 \\
(0.140)\end{array}$ & $\begin{array}{l}-0.140 \\
(0.122)\end{array}$ & $\begin{array}{l}-0.505^{* * *} \\
(0.124)\end{array}$ & $\begin{array}{l}-0.434^{* * *} \\
(0.134)\end{array}$ & $\begin{array}{l}-0.221^{*} \\
(0.128)\end{array}$ \\
\hline $\begin{array}{l}\text { Foreign nationality * born } \\
\text { in Germany }\end{array}$ & $\begin{array}{l}-0.184 \\
(0.313)\end{array}$ & $\begin{array}{l}0.291 \\
(0.270)\end{array}$ & $\begin{array}{l}0.072 \\
(0.283)\end{array}$ & $\begin{array}{l}0.108 \\
(0.305)\end{array}$ & $\begin{array}{l}-0.518^{* *} \\
(0.261)\end{array}$ \\
\hline R-squared & 0.11 & 0.10 & 0.18 & 0.14 & 0.07 \\
\hline No. of observations & 8,672 & 8,886 & 8,819 & 8,261 & 8,913 \\
\hline \multicolumn{6}{|c|}{ FEMALES } \\
\hline Independent variables & Driving & Financial & Leisure & Career & Health \\
\hline Constant & $\begin{array}{l}-0.796 \\
(0.822)\end{array}$ & $\begin{array}{l}-0.086 \\
(0.673)\end{array}$ & $\begin{array}{l}4.031^{* * *} \\
(0.790)\end{array}$ & $\begin{array}{l}-0.524 \\
(0.858)\end{array}$ & $\begin{array}{l}2.466^{* * *} \\
(0.803)\end{array}$ \\
\hline Ethnic Persistence Factor & $\begin{array}{l}-0.124 \\
(0.090)\end{array}$ & $\begin{array}{l}-0.027 \\
(0.081)\end{array}$ & $\begin{array}{l}-0.201^{* *} \\
(0.094)\end{array}$ & $\begin{array}{l}-0.407^{* * *} \\
(0.095)\end{array}$ & $\begin{array}{l}-0.265^{* * *} \\
(0.100)\end{array}$ \\
\hline Assimilation Factor & $\begin{array}{l}0.059 \\
(0.095)\end{array}$ & $\begin{array}{l}0.033 \\
(0.091)\end{array}$ & $\begin{array}{l}0.163^{*} \\
(0.097)\end{array}$ & $\begin{array}{l}0.256^{* *} \\
(0.106)\end{array}$ & $\begin{array}{l}-0.032 \\
(0.102)\end{array}$ \\
\hline Foreign nationality & $\begin{array}{l}-0.434^{* * *} \\
(0.120)\end{array}$ & $\begin{array}{l}-0.173 \\
(0.105)\end{array}$ & $\begin{array}{l}-0.542^{* * *} \\
(0.109)\end{array}$ & $\begin{array}{l}-0.362^{* * *} \\
(0.119)\end{array}$ & $\begin{array}{l}-0.048 \\
(0.123)\end{array}$ \\
\hline $\begin{array}{l}\text { Foreign nationality * born } \\
\text { in Germany }\end{array}$ & $\begin{array}{l}0.210 \\
(0.314)\end{array}$ & $\begin{array}{l}0.385 \\
(0.259)\end{array}$ & $\begin{array}{l}0.252 \\
(0.291)\end{array}$ & $\begin{array}{l}0.150 \\
(0.305)\end{array}$ & $\begin{array}{l}0.325 \\
(0.272)\end{array}$ \\
\hline R-squared & 0.13 & 0.07 & 0.18 & 0.19 & 0.06 \\
\hline No. of observations & 8,889 & 9,538 & 9,456 & 8,635 & 9,606 \\
\hline
\end{tabular}

${ }^{a}$ Robust standard errors in parentheses clustered at the household level.

b OLS regressions include additional controls for age, years of education, marital status, total net household income in $10,000 \mathrm{~s}$ Euros and body height.

${ }^{*}$ significant at $10 \%$; ${ }^{* *}$ at $5 \%$; ${ }^{* *}$ at $1 \%$.

Besides providing a better understanding of the sources of individual risk attitudes, our empirical findings help better understand differences in economic assimilation across immigrants of different ethnic origins. The degrees of ethnic persistence and assimilation vary systematically across different immigrant groups. As was also suggested by Hatton and Leigh (2011), immigrants assimilate not only as individuals, but also as ethnic communities. Since the different groups are also affiliated with different degrees of risk aversion, this may contribute to explaining systematic variation across ethnic groups in economic outcomes influenced by individuals' willingness to take risks, such as self-employment rates or labor market success (Constant et al. 2006).

The evidence presented here furthermore sheds some new light on the fundamental question of what determines economic assimilation. The literature beginning with the seminal study by Chiswick (1978) stresses the acquisition of host country specific human capital, notably language capacity, as the key factor of labor market adjustment. Our evidence suggests that the acquisition of behaviorally and economically relevant attitudes plays a relevant part in this adjustment process. The acquisition of attitudes seems to be positively associated especially with familiarity with the host country language. 
Finally, our results clarify the mechanisms behind similarities in risk proclivity, and thereby economic outcomes, across generations. In our sample, first generation immigrants appear more risk averse than second generation immigrants. Our analysis reveals that this observation does not hold when controlling for the individual degrees of ethnic persistence and assimilation. In other words, individual risk attitudes appear to be transmitted from parents to children. However, while the intergenerational transmission from parents to children is clearly important, our analysis of the adaptation behavior of immigrants suggests that acquisition of social norms is an essential factor in the formation of individual attitudes.

\section{Endnotes}

${ }^{1}$ Dohmen et al. (2012) provide evidence for the intergenerational transmission of risk attitudes.

${ }^{2}$ The exact wording of the question is: "How do you see yourself: Are you generally a person who is fully prepared to take risks? Please tick on a box on the scale, where the value 0 means: 'unwilling to take risks' and the value 10 means: 'fully prepared to take risks'."

${ }^{3}$ Unlike countries like the US where the 'ius soli' dominates, being born in Germany does not automatically grant German citizenship to individuals.

${ }^{4}$ While the GSOEP 2004 wave contains roughly 22,000 individuals, our sample is reduced because we exclude all observations with missing values on at least one variable required for the analysis.

${ }^{5}$ We have also performed the entire analysis using the alternative approach of the principal factors and found the same qualitative results. We present the results based on the principal-components factor method, since the factor patterns are easier to interpret.

${ }^{6}$ The fact that most of the immigration from Eastern Europe occurred over the last decade explains why we do not observe a second generation in our sample.

${ }^{7}$ We have also run non-linear models treating the position on the scale as an ordered outcome. The results obtained from an ordered probit are qualitatively identical to those obtained from the linear model. We only report OLS results, since they are easier to interpret.

${ }^{8}$ We refer to West Europeans because the ethnic persistence and assimilation measures cannot be computed for native Germans. We expect that Western immigrants are in general relatively similar to Germans. In other words, our experiment comes close to an illustration of what would happen, if non-Western immigrants would adapt to the behavior of the native population.

Competing interests

The IZA Journal of Labor Policy is committed to the IZA Guiding Principles of Research Integrity. The authors declare that they have observed these principles.

We thank an anonymous referee and the responsible editor Denis Fougère for valuable comments. We also thank the participants of the 5th AM2 at IZA Bonn for their useful comments and in particular we are grateful to Professor Francis Vella for his valuable insights. We are also thankful to the participants of the 78th Annual Conference of the Southern Economic Association Meeting in DC for their interesting questions and helpful remarks. Lastly, we thank the participants of the Virginia Commonwealth University economics seminar for their constructive feedback and in particular we are appreciative of Professor Leslie Stratton's detailed, insightful, and constructive comments as well as her encouragement. Financial support from Volkswagen Foundation for the IZA project on "The Economics and Persistence of Migrant Ethnicity" is also gratefully acknowledged. 


\section{Author details}

'ZEW, University of Kassel and IZA, ZEW, P.O. Box 103443, Mannheim 68034, Germany. ${ }^{2}$ George Washington University, Temple University, DIW DC and IZA, 1800 K Street NW, Suite 716, Washington DC 20006, USA. ${ }^{3}$ Department of Economics, University of Leicester and IZA, University of Leicester, University Road, LE1 7RH, Leicester, UK. ${ }^{4}$ IZA and Bonn University, IZA, P.O. Box 7240, Bonn D-53072, Germany.

Received: 25 July 2012 Accepted: 22 August 2012

Published: 18 October 2012

\section{References}

Bonin H, Dohmen T, Falk A, Huffman D, Sunde U (2007) Cross-sectional earnings risk and occupational sorting: the role of risk attitudes. Labour Econ 14(6):926-937

Bonin H, Constant A, Tatsiramos K, Zimmermann KF (2009) Native-migrant differences in risk attitudes. Appl Econ Lett 16(15):1581-1586

Camerer C, Hogarth R (1999) The effects of financial incentives in experiments: a review and capital-labor-production framework. Journal of Risk and Uncertainty 19(1):7-42

Chiswick BR (1978) The effect of Americanization on the earnings of foreign-born men.J Polit Econ 86(5):897-921

Constant A, Gataullina L, Zimmermann KF (2006) Gender, ethnic identity and work. IZA Discussion Paper No 2420, http://ftp.iza.org/dp2420.pdf

Constant A, Gataullina L, Zimmermann KF (2009) Ethnosizing immigrants. Journal of Economic Behavior and Organization 69(3):274-287

Dohmen T, Falk A, Huffman D, Sunde U, Schupp J, Wagner GG (2011) Individual risk attitudes: measurement determinants, and behavioral consequences. J Eur Econ Assoc 9(3):522-550

Dohmen T, Falk A, Huffman D, Sunde U (2012) The intergenerational transmission of risk and trust attitudes. Rev Econ Stud 79(2):645-677

Ekelund J, Johansson E, Järvelin M-R, Lichtermann D (2005) Self-employment and risk aversion - evidence from psychological test data. Labour Econ 12(5):649-659

Hatton TJ, Leigh A (2011) Immigrants assimilate as communities, not just as individuals. J Popul Econ 24(2):389-419

Rivers L, Arvai J, Slovic P (2010) Beyond a simple case of black and white: searching for the white male effect in the African-American community. Risk Analysis 30(1):65-77

Schupp J, Wagner GG (2002) Maintenance of and innovation in long-term panel studies: the case of the German SocioEconomic Panel (GSOEP). Allgemeines Statistiches Archiv 86(2):393-408

doi:10.1186/2193-9039-1-5

Cite this article as: Bonin et al: Ethnic persistence, assimilation and risk proclivity. IZA Journal of Migration 2012 $1: 5$

Submit your manuscript to a SpringerOpen ${ }^{\circ}$ journal and benefit from:

- Convenient online submission

Rigorous peer review

- Immediate publication on acceptance

- Open access: articles freely available online

- High visibility within the field

Retaining the copyright to your article

Submit your next manuscript at $\gg$ springeropen.com 